LeobeCK, M. E. \& KLeIN, H. P. (1956). J. gen. Microbiol. 14, 281-289

\title{
Substrates for Myxococcus virescens with Special Reference to Eubacterial Fractions
}

\author{
By MAUDE E. LOEBECK* and H. P. KLEIN $\dagger$ \\ Department of Microbiology, University of Washington School of Medicine
}

\begin{abstract}
SUMMARY: It was found that a mutant strain of Myxococcus virescens, able to grow dispersed in liquid media, oxidized the cytoplasmic lipids and proteins of Escherichia coli. Cell walls and nucleic acids of $E$. coli were not oxidized, and the acid soluble fraction was only slightly oxidized. It was also observed that the cytoplasmic contents of intact cells of $E$. coli were not available for oxidation. Glucose and starch were oxidized by the strain of Myxococcus virescens used.
\end{abstract}

Many of the fruiting terrestial myxobacteria grow and produce fruiting bodies in the presence of other micro-organisms or in the presence of substances obtained from micro-organisms (Vahle, 1909; Pinoy, 1921; Solntseva, 1939; Oetker, 1953). The nature of the substrates for myxobacterial growth is not clear, however, although some indication may be inferred from the observations of Snieszko, McAllister \& Hitchner (1943) that aqueous and saline extracts of disintegrated eubacterial cells proved superior to ethanol, acetone and ether extracts in the cultivation of myxobacteria. The present study, part of an investigation of the nutrition of Myxococcus virescens (Loebeck, 1954), was undertaken to determine what portion of the eubacterial cell is oxidized by this organism. Beebe (1941-2) and Singh (1947) observed that members of the genus Myxococcus are best isolated from enrichment cultures made with soil samples spread on bacterial streaks. In the present work, Escherichia coli was used as the substrate organism. Organisms were grown in media containing radioactive carbon, after which they were fractionated into various chemical classes and given to respiring myxobacteria. In other experiments, purified cell walls and cytoplasmic contents of $\boldsymbol{E}$. coli were used as substrates for respiring myxobacteria. Because of the controversial data on the nutritive value of carbohydrates for these organisms (Stanier, 1942; Clark, 1954), uniformly labelled glucose and starch were also tested as substrates for oxidation by suspensions of myxobacteria. In each case, the respired carbon dioxide was collected and assayed for radioactivity.

\section{METHODS}

Organisms. The organism used in this study was a variant of Myxococcus virescens, M57. The mutant differed from the parent strain in that it was able to grow in a dispersed state when shaken on a rotary shaker. It had originally been obtained by repeated transfers of swarm cells from Tryptone agar to

* Present address : Roswell Park Memorial Institute, Buffalo 3, New York.

$\dagger$ Present address: Brandeis University, Waltham, Massachusetts. 
Tryptone broth. The mutant strain was still able to grow and fruit on bacterial streaks, but did not fruit in liquid cultures.

Escherichia coli, obtained from Dr E. J. Ordal, was the substrate organism.

Media. Escherichia coli was grown in a modification of the defined medium of Waring \& Werkman (1942). Uniformly labelled ${ }^{14} \mathrm{C}$-fructose, which was obtained from Tracerlab, Inc., Boston, Mass., was sterilized separately and added to the previously sterilized medium to a final concentration of $0.2 \%$ $(\mathrm{w} / \mathrm{v})$. Litre flasks, containing $250 \mathrm{ml}$. of medium, were inoculated with the washings of a $24 \mathrm{hr}$. heart infusion slope culture, and shaken on a rotary shaker at approximately $25^{\circ}$ until a good turbidity was obtained, usually $24 \mathrm{hr}$.

Myxococcus virescens was grown on $\mathbf{0 . 4} \%$ (w/v) Difco Tryptone. Twenty ml. of a $24 \mathrm{hr}$. culture from this medium were used as the inoculum for litre flasks containing $250 \mathrm{ml}$. These flasks were shaken on a rotary shaker at approximately $25^{\circ}$.

Structural fractionation of labelled Escherichia coli. Purified cell walls were obtained by the method of Salton \& Horne (1951), with slight modification. Cells of $E$. coli were disintegrated in water and the supernatant fluid containing the cytoplasmic constituents was retained for other experiments. The cell walls were then suspended in $\mathrm{M}-\mathrm{NaCl}$ and subsequently washed with distilled water. Electron micrographs, taken at various stages in the purification of the cell walls, were used to determine whether the cell walls had been freed from whole organisms and cytoplasmic debris.

Biochemical fractionation of the cytoplasmic supernatant from disrupted Escherichia coli. The method of fractionation of Schneider (1945) was used. The trichloroacetic acid used for the precipitations was toxic to the myxobacteria and it was removed by evaporating each fraction to dryness over a steam bath.

Procedure for the oxidation of radioactive material by myxobacterial cells. Twenty-four to $32 \mathrm{hr}$. cultures of myxobacteria were harvested by centrifugation from the Tryptone medium, and washed twice with approximately $50 \mathrm{ml}$. tap water. Ordinary Warburg vessels were fitted with rubber vaccine-bottle tops and the centre wells filled with $0 \cdot 2 \mathrm{ml} .19 \mathrm{~N}-\mathrm{NaOH}$. The main compartment of each vessel received $2-3 \mathrm{ml}$. of freshly collected myxobacteria suspended in distilled water, usually about $10-25 \mathrm{mg}$. dry weight. The labelled fraction being tested was added to the side arm, and the side arm and the top were both sealed. The reactions of the myxobacterial suspensions and the labelled fractions at the time of addition were approximately neutral. The vessel was tipped and placed on a mechanical shaker at $c .25^{\circ}$. At the end of the shaking period, usually $5 \mathrm{hr}$, $\mathbf{0 \cdot 3} \mathrm{ml}$. $\mathrm{N}-\mathrm{HCl}$ was injected into the main compartment through the vaccine top to release bound carbon dioxide and the vessel was shaken $1 \mathrm{hr}$. more, after which the $\mathrm{NaOH}$ was removed from the centre well and the carbonate precipitated as barium carbonate with $0.5 \mathrm{ml} . \mathrm{N}-\mathrm{BaCl}_{2}$. The carbonate precipitate was filtered, washed, weighed and counted in a Tracerlab gas-flow counter.

Experiments with growing organisms were conducted in a similar manner, using larger Warburg vessels. These contained $25 \mathrm{ml}$. of $0.1 \%(\mathrm{w} / \mathrm{v})$ Tryptone in 
the main compartment of the vessel. The radioactive sample was added to the side arm and the vessel contents sterilized by autoclaving at $120^{\circ}$ for $20 \mathrm{~min}$. $1 \mathrm{ml} .19 \mathrm{~N}-\mathrm{NaOH}$ was pipetted into the centre well, and the vessel inoculated with $10 \mathrm{ml}$. of a $48 \mathrm{hr}$. Tryptone broth culture of Myxococcus virescens. The cultures were grown on a mechanical shaker for $48 \mathrm{hr}$. or until a good turbidity was obtained, after which the respired $\mathrm{CO}_{2}$ was precipitated from the centre well as before.

Radioactive carbon determinations. Carbon combustions on all samples to be assayed for radioactivity were performed by the wet-oxidation method of Van Slyke \& Folch, using Barker's apparatus (Calvin, Heidelberger, Reid, Talbert \& Yankowich, 1949).

Radioactive glucose and starch. These were prepared in our laboratory by Dr A. Markovitz, according to the method of Putman, Hassid, Krotkov \& Barker (1948).

\section{RESULTS}

Manometric experiments with unlabelled substrates

In an effort to find suitable carbon sources for the organism, manometric studies were performed by conventional techniques of measurement of oxygen uptake in the Warburg respirometer at $31^{\circ}$.

The organisms for such experiments were grown in the following manner: $50 \mathrm{ml}$. flasks containing $12.5 \mathrm{ml}$. of $0.45(\mathrm{w} / \mathrm{v})$ Tryptone were inoculated with $\mathbf{7 . 0} \mathrm{ml}$. of $48 \mathrm{hr}$. culture from the same medium, and grown for $24 \mathrm{hr}$. at c. $25^{\circ}$ on the rotary shaker. These cultures were used as the inoculum for $150 \mathrm{ml}$. of the same medium contained in $500 \mathrm{ml}$. flasks, which were shaken for an additional $24 \mathrm{hr}$. Organisms were harvested by centrifugation, and washed twice with tap water, after which they were suspended in $c .20 \mathrm{ml}$. tap water. $1 \mathrm{ml}$. of this suspension was used per Warburg vessel, and $1.0 \mathrm{ml}$. of Sorenson's $0 \cdot 07 \mathrm{~m}$-phosphate buffer ( $\mathrm{pH} 7 \cdot 0$ ) was also added to the main compartment of each vessel. Substrates were added in $0 \cdot 2 \mathrm{ml}$. volumes to the side arm.

Table 1. Oxygen uptake of resting Myxococcus virescens, $M 57$

Substrate added
None
Pyruvate
Glucose
Beta-alanine
Malate
Starch

$\begin{array}{cc}\begin{array}{c}\mu \text { mole added/ } \\ \text { vessel }\end{array} & \begin{array}{c}\mathrm{O}_{2} \text { uptake }(\mu \mathrm{l} . / \mathrm{hr} . / \\ \text { vessel })\end{array} \\ - & 47 \\ 2 \cdot 0 & 50 \\ 0 \cdot 4 & 45 \\ 2 \cdot 0 & 43 \\ 20 \cdot 0 & 35 \\ 2 \cdot 0 & 45\end{array}$

The rate of oxygen uptake with glucose, pyruvate, beta-alanine, malate and starch as substrate is shown in Table 1. It is apparent that none of the substrates tested stimulated oxygen uptake. Heat-killed bacteria and milk, used in a similar experiment also failed to raise the rate of oxygen uptake. In other experiments, in an effort to reduce endogenous oxygen consumption, cell suspensions were shaken for varying periods of time, up to $14 \mathrm{hr}$., in tap 
water or in phosphate buffer. Such measures, however, were not successful in lowering the high autorespiration.

Additional manometric experiments were performed to test the ability of the organisms to oxidize substrates, after having been grown in their presence. For this organisms were grown in Tryptone medium containing respectively $0.5 \%(\mathrm{w} / \mathrm{v})$ glucose, maltose or starch, and then tested for their endogenous rate and rate of oxidation of these substrates. The data, shown in Table $\mathbf{2}$, reveal the difference between endogenous rates and the others to be so slight that no significance can be attached to them.

Table 2. Oxygen uptake by Myxococcus virescens, M 57, previously grown in the presence of glucose, maltose or starch

\begin{tabular}{|c|c|c|c|c|}
\hline \multirow[b]{2}{*}{$\begin{array}{l}\text { Organisms } \\
\text { grown on }\end{array}$} & \multirow[b]{2}{*}{ Endog. rate } & \multicolumn{3}{|c|}{ Oxygen uptake $(\mu \mathrm{l} . / \mathrm{hr}$./vessel $)$} \\
\hline & & $\begin{array}{l}\text { Glucose } \\
\text { (20 mg.) }\end{array}$ & $\begin{array}{l}\text { Maltose } \\
\text { (20 mg.) }\end{array}$ & $\begin{array}{c}\text { Starch } \\
(20 \mathrm{mg} .)\end{array}$ \\
\hline Glucose & 72 & 71 & n.t. & n.t. \\
\hline Maltose & 45 & n.t. & 60 & n.t. \\
\hline Starch & 50 & n.t. & n.t. & 45 \\
\hline
\end{tabular}

\section{Oxidation of radioactive substrates}

The experiments cited might be interpreted as indicating that either none of the substances tested serve as substrates for oxidation, or any one or all of them could be oxidized with a concomitant reduction in autorespiration. In an effort to test these possibilities, radioactive substrates were prepared (see under Methods), and given to respiring myxobacteria. The oxidation of these substrates by resting myxobacteria is shown in Tables 3 and 4. Data for growing cells are given in Table 5 .

\section{DISCUSSION}

Early workers (Quehl, 1906; Vahle, 1909) were unable to enhance the growth of myxobacteria with glucose or starch. Imshenetskii (1941), working with a strain of Sporocytophaga myxococcoides, reported a toxic effect of glucose that was not due to the oxidation-reduction potential. Stanier (1942), using a strain of $S$. myxococcoides and two strains of Cytophaga sp., found that the toxicity was explained in part by the presence of toxic materials formed during heat sterilization. Clark's (1954) data, however, show an inhibition with filtered or heat-sterilized glucose. Solntseva (1941) reported the disappearance of $\mathbf{2 0 . 5}$ and $18.5 \%$ glucose respectively from cultures of Chondromyces and Melittangium spp., and Mishustin (1942) reported the disappearance of $3 \%$ of the products resulting from starch hydrolysis with a strain of Chondrococcus sp.

Our results show that unheated and autoclaved glucose were oxidized to the same extent, within the limit of error, i.e. 16 and $17 \%$, respectively. It would seem, however, that autoclaved glucose may be somewhat toxic to growing organisms, since growth in the control vessel without glucose gave an optical 
Substrates for Myxococcus virescens

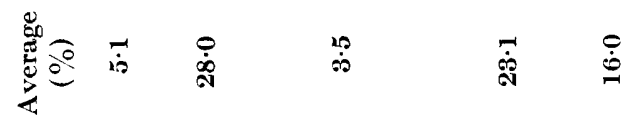

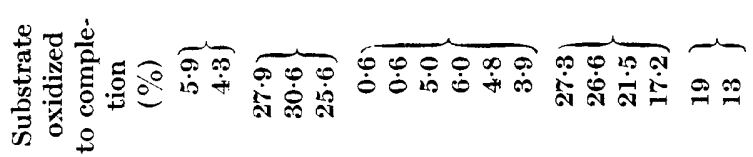

言

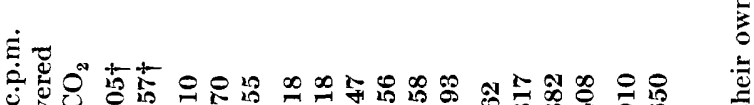

3

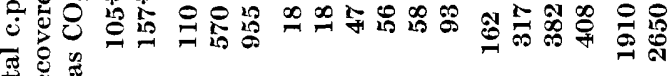

要

$*$

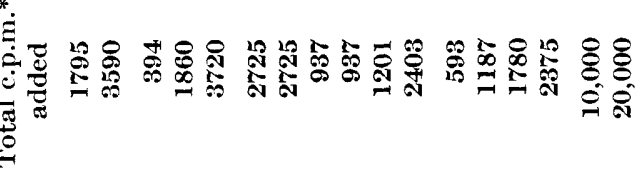

s

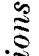

胥墭

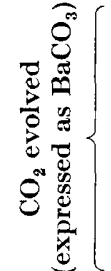

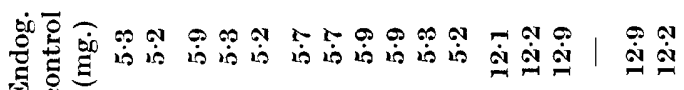

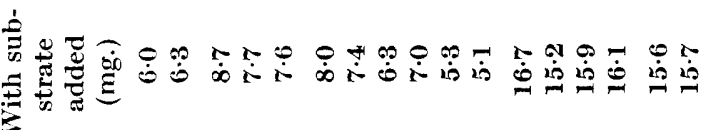
范

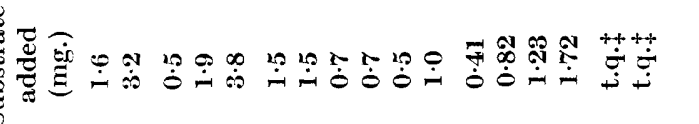

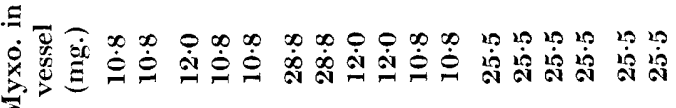

ष

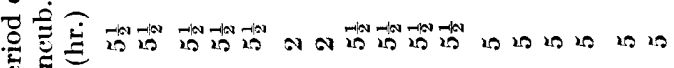
$\approx$

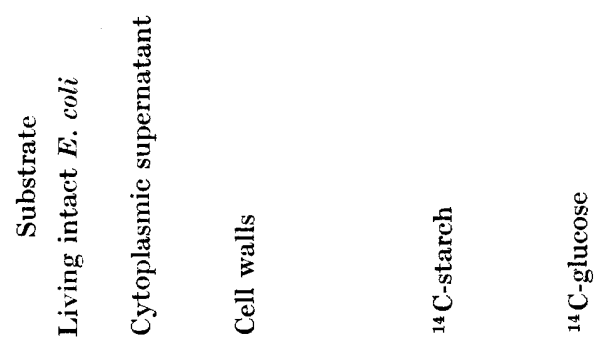




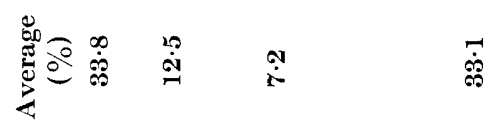

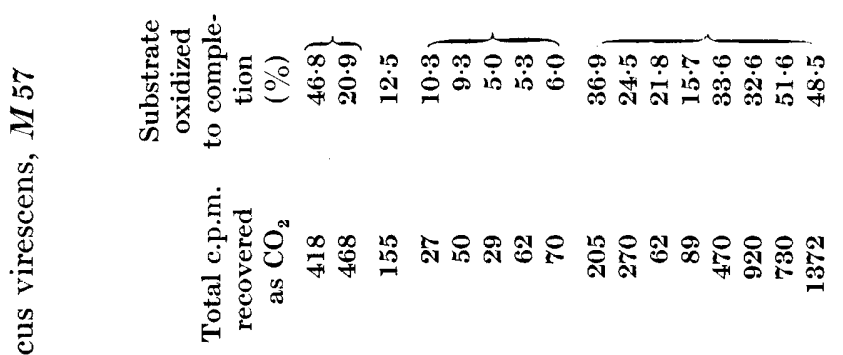

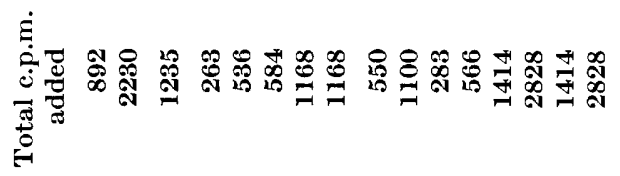

(艹)

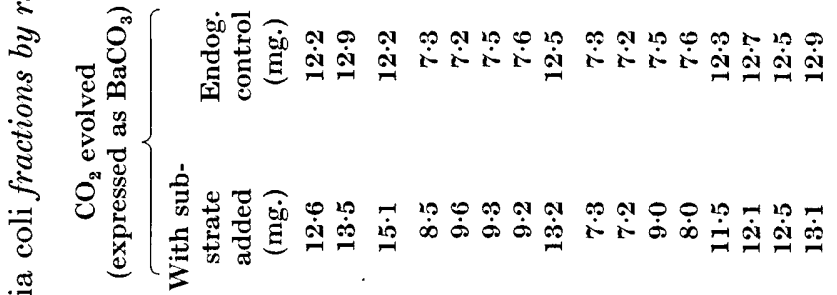

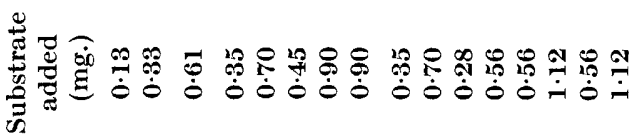

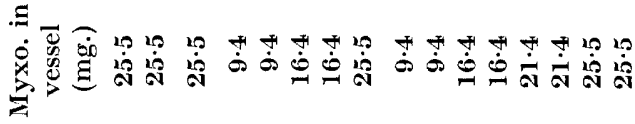

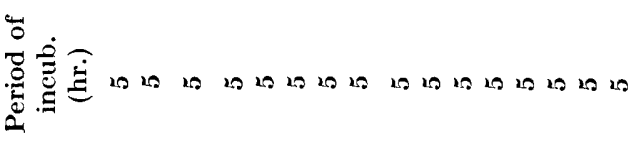

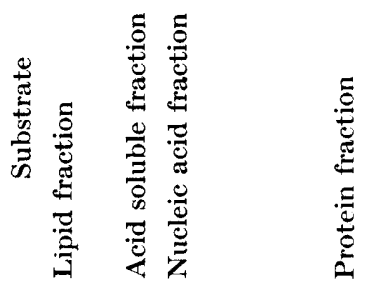




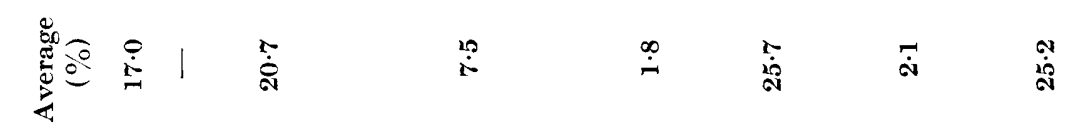

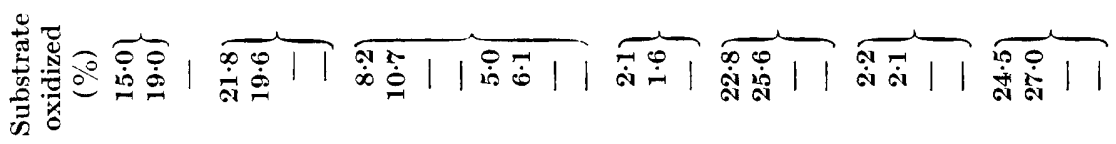

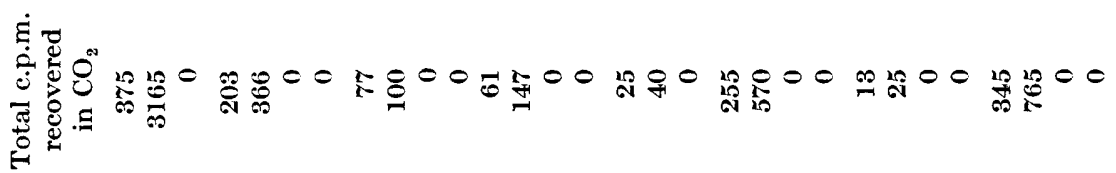

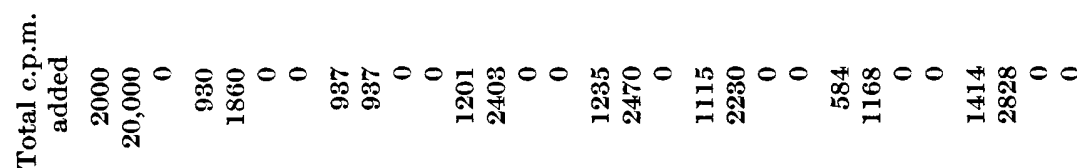

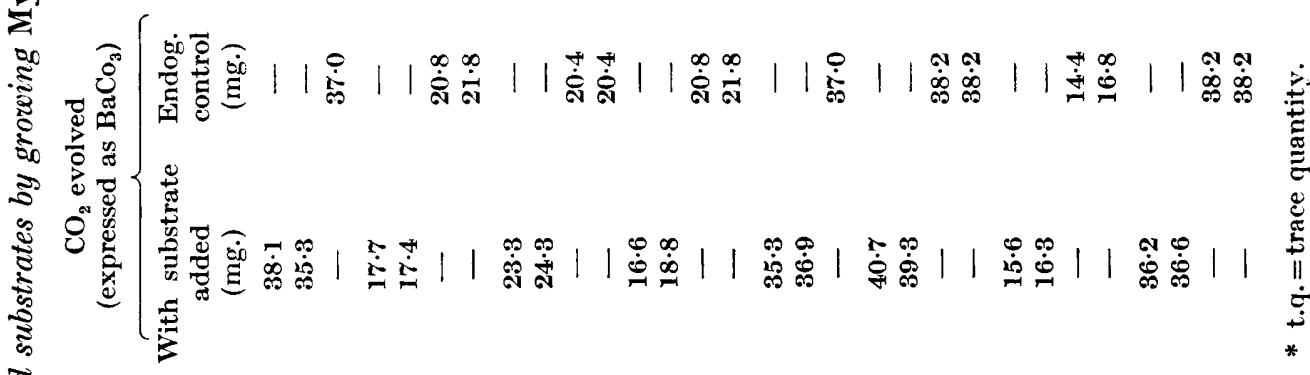

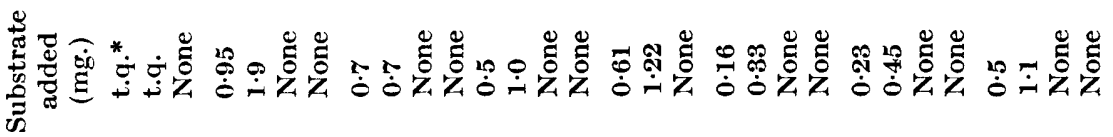

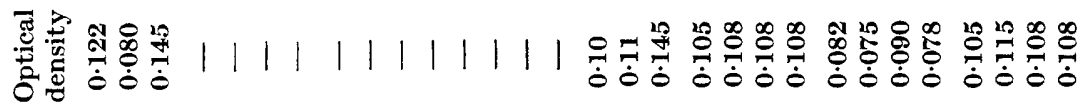
is

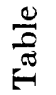

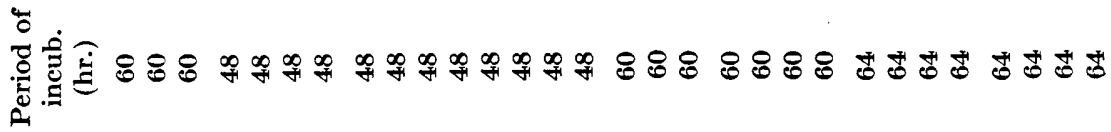

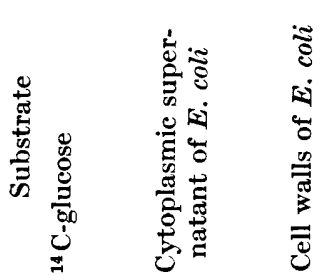

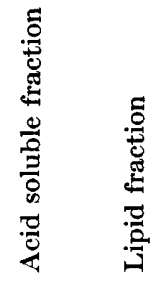

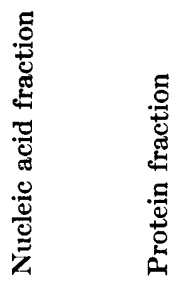


density reading of $\mathbf{0} \cdot \mathbf{1 4 5}$, whereas the readings obtained from the vessel containing a small quantity of glucose were $0 \cdot 122$ and, for the larger quantity, $0 \cdot 080$.

Of paramount importance is the observation that, while the proteins and lipids of killed Escherichia coli were readily oxidized by Myxococcus virescens, the protoplasmic contents of intact living Escherichia coli were not available to the myxobacteria. The average percentage of labelled carbon appearing in the respired carbon dioxide, with living $E$. coli as a substrate, was $5 \cdot 1 \%$. This represents a maximum figure since some, if not all, of this is derived from the endogenous respiration of $E$. coli.

The average value obtained for the complete oxidation of the purified cell walls of Escherichia coli by resting myxobacteria is $3.5 \%$. It should be emphasized that the cell-wall preparations may contain small amounts of some contaminating components which the myxobacteria are able to utilize. In this connexion, it is interesting to note that, judging from their appearance in the electron microscope, some cell-wall preparations were more easily washed than others, and that these fractions gave the lowest amount of labelled $\mathrm{C}$ in the respired $\mathrm{CO}_{2}$. In the experiment with growing cells, the extent of oxidation of cell wall was only slightly higher and this may well be the result of hydrolysis of cell-wall material during autoclaving.

This work was supported in part by University of Washington funds for medical and biological research. We wish to thank Dr E. J. Ordal for his encouragement and helpful suggestions during the course of these studies.

\section{REFERENCES}

Beebe, J. M. (1941-2). Studies on the myxobacteria. Iowa State Coll. J. Sci. 15, 319. Calvin, M., Heidelberger, C., Reid, J. C., Talbert, B. M. \& Yankowich, P. F. (1949). Isotopic Carbon. New York: John Wiley and Son.

Clark, W. A. (1954). Effect of carbohydrates on some myxobacteria. J. Bact. 67, 589.

Imshenerskir, A. A. (1941). On the 'toxic' action of glucose on myxobacteria. Microbiology, Moscow, 10, 179.

Loebeck, M. E. (1954). Studies on the terrestrial fruiting myxobacteria. Ph.D. Thesis: University of Washington.

Mishustin, E. N. (1942). Chondrococcus corolloides (Thaxter) and factors determining the cycle of its development. Microbiology, Moscow, 11, 178.

Oetкer, H. (1953). Untersuchungen über die Emährung einiger Myxobakterien. Arch. Mikrobiol. 19, 206.

Pinoy, P. E. (1921). Sur les Myxobacteries. Ann. Inst. Pasteur, 35, 487.

Putman, E. W., Hassid, W. Z., Krotkov, G. \& Barker, H. A. (1948). Preparation of radioactive carbon-labelled sugars by photosynthesis. J. biol. Chem. 173, 785.

Quent, A. (1906). Untersuchungen über die Myxobakterien. Z Zbl. Bakt. (2. Abt.), $16,9$.

Salton, M. R. J. \& Horne, R. W. (1951). Studies on the bacterial cell wall: II. Methods of preparation and some properties of cell walls. Biochim. biophys. Acta, 7, 177.

Schneider, W. C. (1945). Phosphorus compounds in animal tissue: I. Extraction and estimation of desoxypentose nucleic acid and of pentose nucleic acid. J. biol. Chem. 161, 293. 
SiNGH, B. N. (1947). Myxobacteria in soils and composts, their distribution, number and lytic action. J. gen. Microbiol. $1,1$.

Snieszko, S. F., McAllister, J. \& Hitchner, E. R. (1943). On the biology of certain myxobacteria. Quart. Bull. Polish Inst. Arts Sci. Amer. 1, 651.

Solntseva, L. I. (1939). On the lysis of phytopathogenic bacteria caused by Myxobacteriales. Microbiology, Moscow, 8, 700.

Solntseva, L. I. (1941). The biology of myxobacteria: II. The genera Melittangium and Chondromyces. Microbiology, Moscow, 10, 505.

Stanier, R. Y. (1942). Cytophaga group: A contribution to the biology of myxobacteria. Bact. Rev. 6, 143.

VAHLE, C. (1909). Vergleichende Untersuchungen über die Myxobacteriaceae. Z Zbl. Bakt. (2. Abt.), 25, 178.

WARING, H. S. \& WerkmaN, C. H. (1942). Growth of bacteria in iron-free medium. Arch. Biochem. 1, 303.

(Received 29 August 1955) 